Bioscientia Medicina: Journal of Biomedicine \&

Translational Research

Journal Homepage: www.bioscmed.com

\title{
Anatomical and Hemodynamic Evaluation of Mitral Stenosis Patients with Echocardiography
}

\section{Muhammad Mukti ${ }^{*}$, Erwin Sukandi², Ali Ghanie ${ }^{2}$, Taufik Indrajaya ${ }^{2}$, Syamsu Indra $^{2}$}

${ }^{1}$ Subspecialized Residency Training, Department of Internal Medicine, Faculty of Medicine, Universitas Sriwijaya/ Dr Moh Hoesin General Hospital, Palembang, Indonesia

${ }^{2}$ Medical Staff, Cardiovascular Division, Department of Internal Medicine, Faculty of Medicine, Universitas Sriwijaya Universitas Sriwijaya/ Dr Moh Hoesin General Hospital, Palembang, Indonesia

\section{A R T I C L E I N F O \\ Keywords: \\ Echocardiography \\ Mitral stenosis \\ Mitral valve area \\ Severity \\ *Corresponding author: \\ Muhammad Mukti \\ E-mail address: \\ mukti.zn@gmail.com}

All authors have reviewed and approved the final version of the manuscript.

https://doi.org/10.32539/bsm.v5i4.378
A B S T R A C T

Mitral stenosis (MS) is the most common valvular heart disease encountered in developing countries. The cause of MS is almost always chronic rheumatic heart disease. Echocardiography is the single most important diagnostic tool in the evaluation of MS. The objectives are to confirm the etiology, to assess the severity of stenosis, to recommend the type and timing of intervention, to assess other valvular lesions, presence of thrombus, and vegetation. According to current guidelines and recommendations for clinical practice, the severity of MS should not be defined by a single value but rather be assessed by a multimodality approach that determines valve areas, mean Doppler gradients, and pulmonary arterial pressures. The European Society of Echocardiography/American Society of Echocardiography (EAE/ASE) recommendations of measurement method for clinical practice were categorized into three level of recommendations. Mitral valve area (MVA) can be assessed by planimetry using either 2D or 3D imaging, pressure half-time $(\mathrm{PTH})$, the continuity equation, and the proximal isovelocity surface area (PISA) method. These result echocardiographic examinations can increase the accuracy and appropriate management with a good prognosis.

\section{Introduction}

The normal mitral valve complex is a dynamic threedimensional system that allows blood flow to the left ventricle (LV) during diastole and ensures unidirectional pumping function of the heart by tightly closing the left atrium (LA) of the LV during systole. The main components of the mitral complex are the mitral annulus, mitral leaflets, chordae tendineae, and the LV wall with papillary muscles (PMs). 1 Disruption of any of these components can lead to mitral stenosis and mitral regurgitation or a combination of both. 1,2
Mitral stenosis (MS) is characterized by a narrowing of the valve orifice and obstruction of blood flow to the left ventricle. ${ }^{3}$ The most common etiology of mitral stenosis is rheumatic fever, ${ }^{3,4}$ in adult patients more than 90\%.5 The prevalence of MS in Europe and other countries Progress is still about $10 \%$ of cases of left valve heart disease. ${ }^{3,6}$ Meanwhile in Indonesia, cases of mitral stenosis are still found. The exact number is not known, but from the pattern of etiology of heart disease in the polyclinic of Moehammad Hoesin Hospital 
Palembang for 5 years (1990-1994) it was found that $13.94 \%$ with valvular heart disease. ${ }^{4}$ Mitral rheumatic stenosis is more common in women (3:1), data MS at RSUP Dr. M. Djamil Padang in 2012-2016 suffered the most by women (72.3\%).7 Pulmonary hypertension is a complication that often occurs in mitral stenosis, with a complex pathophysiology. 4,8

With the development of knowledge in the field of echocardiography, the role of echocardiography is very important to evaluate valve anatomy and hemodynamic consequences in MS patients, without having to perform invasive catheterization procedures. The severity of MS can be assessed by several screening methods that have been recommended in clinical practice. The results of this echocardiography examination can be a basis for consideration for further management, both medical therapy or the type and time of intervention chosen by taking into account the prognostic aspects of the patient based on the results of the echocardiographic examination and clinical findings. This literature review aims to summarize several methods of anatomical examination and echocardiographic hemodynamics that can be performed in mitral stenosis patients.

\section{Mitral valve anatomy}

The mitral valve is a complex of anatomical and functional structures that are essential for the pumping function of the heart. The main components of the mitral complex are the mitral annulus, mitral leaflets, chordae tendineae (corda), and the LV wall is connected to the papillary muscles (PMs: papillary muscles), this can be seen in Figure $1 .{ }^{1}$

The normal mitral valve apparatus is a dynamic three-dimensional system, which allows blood to flow rapidly into the left ventricle (LV) during diastole and ensures unidirectional pumping function due to the closure of the left atrium (LA) from the LV during systolic. Good valve function depends on the integrity and harmonious interaction of these components and imbalance can result in leakage (regurgitation, insufficiency, incompetence) and narrowing (stenosis), or a combination of regurgitation and stenosis leading to mitral valve dysfunction. 1,2

The mitral annulus represents the junction zone that separates the tissues of the left atrium and the left ventricle, which is a fibrous ring and is also the site of attachment of the mitral leaflet. This is a dynamic structure during the cardiac cycle. This mitral annulus is shaped like a kidney bean, where the commissure diameter (transverse) is greater than the anteroposterior diameter through the leaflet A2-P2.1,2,9

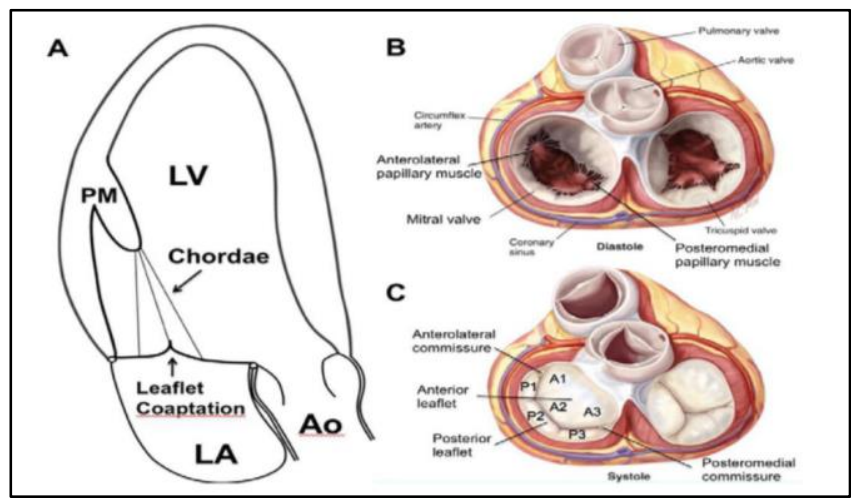

Figure 1. A. Schematic apical long-axis view of the heart during systolic with the apex above. B. Surgical view when the mitral valve is open during diastole. C. Surgical view when the mitral valve is closed during systole (Ao: aorta; LA: left atrium; LV: left ventricle; PM: papillary muscle). ${ }^{1}$

The mitral valve has anterior (A1, A2 and A3) and posterior (P1, P2 and P3) leaflets and variable scissor commissures closing the medial and lateral clefts. The anterior leaflet is about $1.5-2.5 \mathrm{~cm}$ long. 9 The posterior 
leaflet has a wider attachment $(2 / 3)$ to the annulus than the anterior leaflet (1/3, usually $3 \mathrm{~cm}$ ). 1,2,9,10

The normal mitral valve area (MVA) is about 4-6 $\mathrm{cm} 2$. A decrease in MVA below $1.5 \mathrm{~cm} 2$ will result in MS symptoms and at an MVA below $1 \mathrm{~cm} 2$ (severe MS) patients will usually have symptoms at rest. ${ }^{8}$

\section{Anatomical and hemodynamic evaluation with echocardiography}

In mitral stenosis Echocardiography is the most important diagnostic tool in the evaluation of mitral stenosis. Echocardiography has a great role in analyzing valve anatomy, hemodynamics, severity of stenosis and its consequences, assessing other valvular lesions, presence of thrombus and vegetations and for confirming the diagnosis of MS. The results of this echocardiographic assessment can be the basis for recommendations for the type of therapy and the time of intervention. 6,11 Confirmation of the etiology on echocardiography by looking at the differences in the appearance of calcification, commissural fusion and mitral leaflet mobility in cases of rheumatic MS, degenerative MS and congenital MS, this is described in table $1 .{ }^{11}$

Various kinds of echocardiographic window displays that can be used in the assessment and measurement of mitral stenosis patients both qualitatively and quantitatively assessments are summarized in table 2.11

Table 1. Comparison of the three causes of MS. ${ }^{11}$

\begin{tabular}{lccc}
\multicolumn{1}{c}{ Variable } & MS Rheumatism & Congenital MS & Degenerative MS \\
\hline Calcification & Leaflets and commissure & Rarely & Annulus to leaflets \\
commissure & Fusion & Varies & Usually free \\
Leaflet Mobility & Limited & Limited & The ends are usually free \\
\hline
\end{tabular}

Table 2. Summary of echo window display and assessment of mitral stenosis.11

\begin{tabular}{|c|c|c|c|}
\hline Window & Rate $\mathbf{K}$ ualitati $\mathbf{f}$ & Quantitative Assessment & Note \\
\hline PLAX & $\begin{array}{l}\text { Mitral apparatus } \\
\text { morphology, aortic valve } \\
\text { morphology, color Doppler } \\
\text { MR }\end{array}$ & $\begin{array}{l}\text { LA dimensions, aortic annulus, LVd } \\
\text { and LVs dimensions. } \\
\text { Dimensions of the mitral annulus, } \\
\text { mitral leaflets separation, area jet MR } \\
\text { / LA area }\end{array}$ & $\begin{array}{l}\text { Linear LV measurements were } \\
\text { obtained at diastole and } \\
\text { systole. } \\
\text { Value the four characteristics } \\
\text { of the mitral valve. Modification } \\
\text { of appearance to } \\
\text { assess subvalvular pathology }\end{array}$ \\
\hline PSAX & $\begin{array}{l}\text { Mitral valve morphology, } \\
\text { commissural calcification, } \\
\text { aortic valve morphology, } \\
\text { LA, and LAA clot } \\
\text { (thrombus) }\end{array}$ & Mitral valve area with planimetry & $\begin{array}{l}\text { Trace the inner contour of the } \\
\text { narrowest hole in mid-diastole }\end{array}$ \\
\hline A $4 \mathrm{C}$ & $\begin{array}{l}\text { Mitral valve morphology, } \\
\text { MR color jet direction, MR. }\end{array}$ & $\begin{array}{l}\text { Peak and mean gradients, MVA with } \\
\text { IPM, MS VTI, TR peak gradient, TR }\end{array}$ & $\begin{array}{l}\text { In nonlinear mitral } \\
\text { flow, mid-diastole tilt is used }\end{array}$ \\
\hline
\end{tabular}




\begin{tabular}{|c|c|c|c|}
\hline & $\begin{array}{l}\text { spectral doppler } \\
\text { assessment } \\
\text { Mitral anulus dimensions, } \\
\text { tricuspid valve } \\
\text { morphology, and function } \\
\text { IAS, aneurysm } \\
\text { and thrombus }\end{array}$ & severity, mitral leaflet separation & $\begin{array}{l}\text { for IPM ; TR jet area / RA area . } \\
\text { Take the mean of the mitral } \\
\text { leaflet separation obtained from } \\
\text { the PLAX and A4c tampilan } \\
\text { displays }\end{array}$ \\
\hline A5C & Aortic valve a & $\begin{array}{l}\text { LVOT VTI, Doppler to } \\
\text { assess AS and AR }\end{array}$ & $\begin{array}{l}\text { LVOT VTI is obtained by } \\
\text { placing a volume } \\
\text { sample proximal to the aortic } \\
\text { valve avoiding areas of flow } \\
\text { convergence }\end{array}$ \\
\hline A2C & $\begin{array}{l}\text { Mitral valve morphology } \\
\text { LAA clot }\end{array}$ & MR color Doppler and spectral Doppler & $\begin{array}{l}\text { 2- chamber display modification } \\
\text { was used to assess LAA }\end{array}$ \\
\hline
\end{tabular}

MR: Mitral regurgitation, LA: Left atrial, LAA: Left atrial appendage, LVs: Left ventriculars, LVd: Left ventricle diameter, PHT: Pressure half time, MVA: Mitral valve area, VTI: Velocity-time-integral, TR: Tricuspid regurgitation, RA: Right atrial, PLAX: Parasternal long-axis view, PSAX: Parasternal short-axis view, IAS: Interatrial septum, LVOT: Left ventricular outflow tract, AR: Aortic regurgitation, AS: Aortic stenosis, MS: Mitral stenosis.

In MS echocardiography examination, there are several methods of severity assessment that are recommended to be performed on the patient. All modalities such as M-mode, 2D echo and Doppler evaluation should be used in the assessment.11 With M-mode echocardiography, the motion of the mitral leaflet can be evaluated and this view is useful in detecting disorders of the mitral valve. ${ }^{10}$ However the development of 2D echo and Doppler echo has take over the role of the M-mode echo in the diagnosis and assessment of MS severity. In clinical practice, The European Society of Echocardiography / American Society of Echocardiography (ESE/ASE) divides echocardiographic examination methods into three levels of recommendation (table 3 ). 6

Table 3. Recommendation level for echocardiographic examination based on ESE/ASE 20096

\begin{tabular}{cr}
\hline Recommended Level & In Clinical Practice \\
\hline Level 1 & The method is appropriate and recommended for all patients with valvular stenosis. \\
Level 2 & Clinically reasonable methods are used when additional information is needed on a \\
selective patient. & The method is not recommended for routine clinical practice although it may be \\
appropriate for research applications and in rare clinical cases.
\end{tabular}

\section{Mitral valve morphology analysis}

Anatomical evaluation is a major component of the echocardiographic assessment of MS because of its implications for adequate choice of intervention.6 Parameters that need to be assessed regarding valve morphology are as follows, namely thickening, mobility, subvalvular fusion, commissural fusion and valvular calcification. ${ }^{11}$

Echocardiographic examination on the long axis parasternal (PLAX) view can evaluate valve leaf 
thickening and mobility. Cord shortening and thickening were assessed using the PLAX and apical

with regard to the commissure area on the short axis parasternal (PSAX) view. 6,11

The anatomical defects of the mitral valve are expressed in a combination of scores of various components of the mitral apparatus or using an overall assessment of valve anatomy, such as using the Wilkins score (table 4).6,11 The Wilkins score is a quantitative method of evaluating the mitral valve and the mitral apparatus by echocardiography to assess severity. mitral stenosis, each component has a value range of $1-4$, so the minimum value is 4 and the maximum value is 16 . $6,11,12,13,14$

The Wilkins score can be one of the considerations views. The report should also mention disturbances in the anatomical homogeneity of the valves, particularly in conducting intervention, if the Wilkins score $\leq 8$ is good, balloon valvuloplasty (commissurotomy) is performed, if the score is 8-12 without significant calcification, valve repair is recommended and if the score is $\geq 12$, valve replacement is recommended. $13,14,15$ If Wilkins score $\leq 8$, the valve is flexible and not calcified with subvalvular disease, this shows as the best indicator for immediate balloon commissurotomy. In the study of Mughal et al, patients with a Wilkins score $<8$ who underwent percutaneous transvenous mitral commissurotomy (PTMC) had a 95.6\% success rate ( $\mathrm{n}$ $=23) \cdot 12$

Table 4. Wilkins score system for mitral valve based on echocardiographic features 2D. 6

\begin{tabular}{|c|c|c|c|c|}
\hline Score & Mobility & Thickening & Calcification & Subvalvular thickening \\
\hline 1 & $\begin{array}{l}\text { The valve is very } \\
\text { mobile, only the leaf } \\
\text { tip movement is } \\
\text { limited }\end{array}$ & $\begin{array}{l}\text { Mitral leaf thickness is } \\
\text { almost normal ( } 4-5 \mathrm{~mm})\end{array}$ & $\begin{array}{l}\text { Only one area with } \\
\text { increased brightness } \\
\text { (brightness) }\end{array}$ & $\begin{array}{l}\text { Minimal thickening just } \\
\text { below the mitral leaf }\end{array}$ \\
\hline 2 & $\begin{array}{l}\text { Middle and basal } \\
\text { leaves have limited } \\
\text { mobility }\end{array}$ & $\begin{array}{l}\text { Normal middle leaf, } \\
\text { thickening at margins } \\
(5-8 \mathrm{~mm})\end{array}$ & $\begin{array}{l}\text { Bright areas are } \\
\text { scattered along the } \\
\text { leaflet margin }\end{array}$ & $\begin{array}{l}\text { The thickening of the } \\
\text { cord structure extends to } \\
1 / 3 \text { of the length of the } \\
\text { cord }\end{array}$ \\
\hline 3 & $\begin{array}{l}\text { The valve moves } \\
\text { forward diastole ik, } \\
\text { mainly of basalt }\end{array}$ & $\begin{array}{l}\text { Thickening extends } \\
\text { over the entire leaflet } \\
(5-8 \mathrm{~mm})\end{array}$ & $\begin{array}{l}\text { The bright area } \\
\text { extends to the center } \\
\text { of the leaflet }\end{array}$ & $\begin{array}{l}\text { The thickening extends } \\
\text { to the distal } 1 / 3 \text { of the } \\
\text { cord }\end{array}$ \\
\hline 4 & $\begin{array}{l}\text { Leaflet movement is } \\
\text { absent or minimal } \\
\text { during diastole }\end{array}$ & $\begin{array}{l}\text { The valve leaflets are } \\
\text { very thickened (>8-10 } \\
\mathrm{mm})\end{array}$ & $\begin{array}{l}\text { Almost all parts of the } \\
\text { valve leaf tissue are } \\
\text { very bright }\end{array}$ & $\begin{array}{l}\text { Severe thickening and } \\
\text { shortening of the entire } \\
\text { cord structure extending } \\
\text { to the papillary muscles }\end{array}$ \\
\hline
\end{tabular}

The Wilkins score can be one of the considerations in conducting intervention, if the Wilkins score $\leq 8$ is good, balloon valvuloplasty (commissurotomy) is performed, if the score is 8-12 without significant calcification, valve repair is recommended and if the score is $\geq 12$, valve replacement is recommended. 13, 14,15 If Wilkins score $\leq 8$, the valve is flexible and not calcified with subvalvular disease, this shows as the best indicator for immediate balloon commissurotomy.
In the study of Mughal et al, patients with a Wilkins score $<8$ who underwent percutaneous transvenous mitral commissurotomy (PTMC) had a 95.6\% success rate $(\mathrm{n}=23) .12$

\section{Valve thickening}

Rheumatic disease activity increases thickness and limits mobility of the mitral leaflet. Commissural fusion leads to doming of the anterior leaflet which gives a 


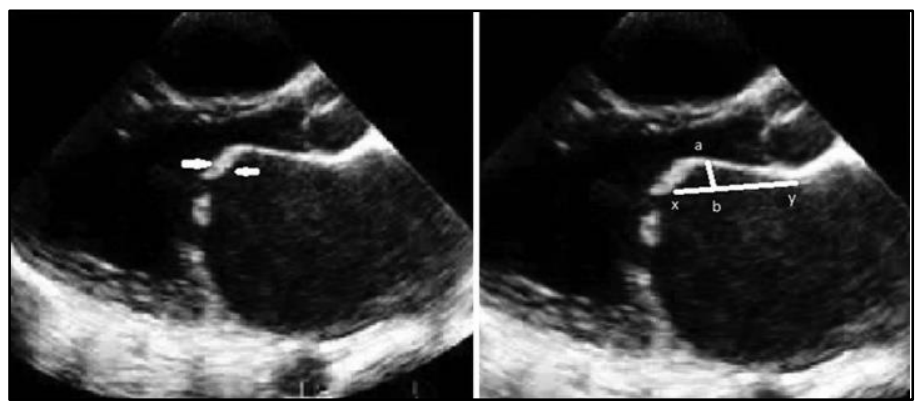

Figure 2. (a) Measuring the thickness of the anterior leaflet tip at diastolic. (b) Objective measurement of leaflet mobility $(\mathrm{ab} / \mathrm{xy})^{11}$

The normal thickness of the mitral leaflet is $2-4 \mathrm{~mm}$. There are 4 levels of thickness on the Wilkins Score. The thickness of the mitral leaflet can be compared with the thickness of the posterior aortic wall. Normal value when the ratio $<1.4$. Light thickening if the ratio is $1.4-2$, moderate thickening if the ratio value is 2 5 and heavy thickening if the ratio is $>5.6$

\section{Valve mobility}

Leaflet mobility was assessed on both the PLAX and apical 4 chamber (A4C) displays. The extent of anterior leaflet doming can be objectively assessed by the Reid scoring system. A line is drawn from the junction of the posterior wall of the aortic root to the tip of the anterior mitral leaflet $(x y=H)$. A plumb line is drawn to the front end of the maximum dome $(a b=\mathrm{L})$. Mobility is expressed as a slope by dividing the height of the dome by the length of the dome, then the mobility assessment can use the $\mathrm{H}$ / L formula (table 7), this can be seen in Figure 2b. 11

Table 5. Objective levels of mitral valve mobility according to the Reid scoring system.11

H/L ratio (ab/xy)

$$
<0.25
$$

$0.25-0.44$

$>0.45$
Level

Light

Medium

Weight
Score

\begin{tabular}{ccc}
$0.25-0.44$ & Medium & 1 \\
& & Weight \\
\hline
\end{tabular}

\section{Subvalvular fusion}

Subvalvular pathology in the arthritic process can affect the entire mitral apparatus. The cords may become thickened, fused, shortened and calcified. 2D echo assessment of the subvalvular structures is essential. Usually, a visual assessment is sufficient to make decisions about MS management. However, an objective assessment can be done using the Lung et al score. (Table 6).5,11 
Table 6. Lung and cormier scores. 5.11

\begin{tabular}{|c|c|}
\hline Echocardiography group & Mitral valve anatomy \\
\hline Group 1 & $\begin{array}{l}\text { AML bending no calcification and mild Subvalvular disease (thin } \\
\text { cord, the length of } \geq 10 \mathrm{~mm}\end{array}$ \\
\hline Group 2 & 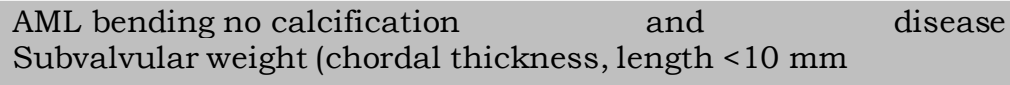 \\
\hline Group 3 & $\begin{array}{l}\text { Mitral valve calcification of any extent, as assessed by } \\
\text { fluoroscopy, regardless of the subvalvular apparatus }\end{array}$ \\
\hline
\end{tabular}

AML: anterior mitral leafle

Cord length is measured on A4C or A2C. Mild subvalvular disease is indicated when the cord length is more than $10 \mathrm{~mm}$. Severe subvalvular disease is diagnosed when the chordae are $<10 \mathrm{~mm} .{ }^{5,11}$

Modified PLAX and A4C views on 2D transthoracic echocardiography (TTE) and 2D transesophageal echocardiography (TEE) can be used to properly visualize chordal abnormalities in mitral stenosis. 5,9,10,11 This can be seen in Figures 3 and 4.

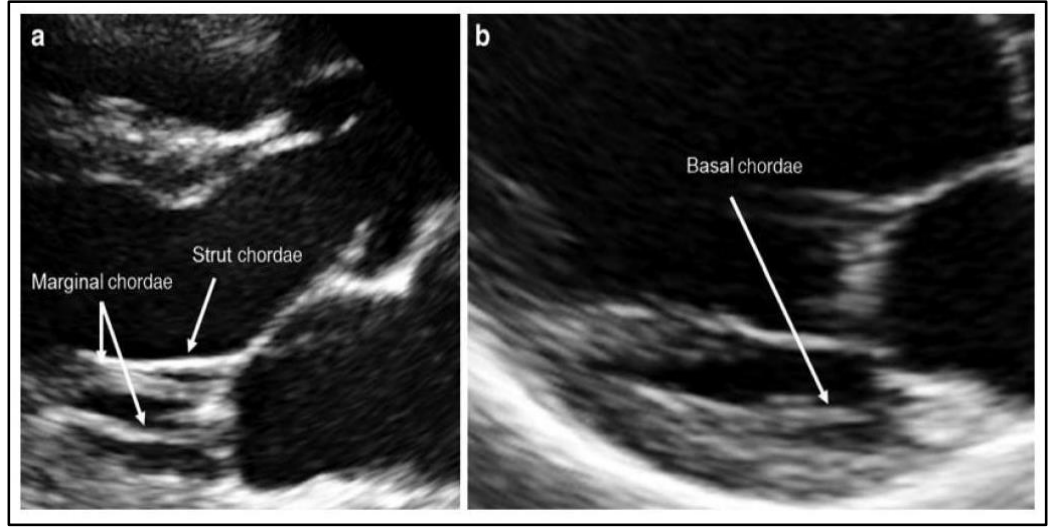

Figure 3. PLAX 2D display where there are 3 types of korda (a. strut and marginal; b. basal) that can be distinguished. 9 


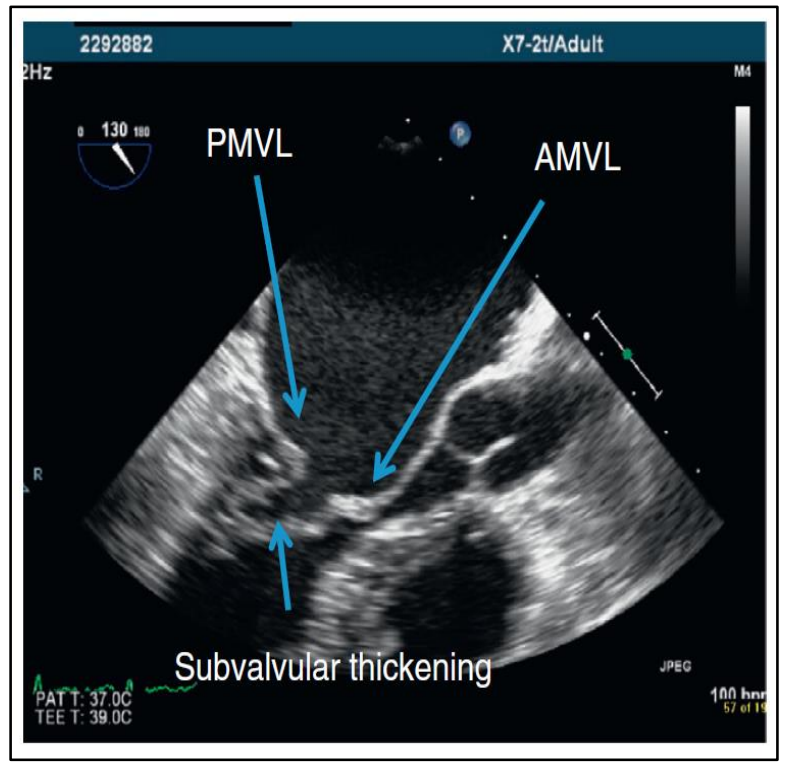

Figure 4. TEE long axis view of a patient with severe mitral stenosis, diastolic dominance and hockey stick shape of the mitral valve anterior leaflet (AMVL) and restricted posterior leaflet (PMVL). The subvalvular apparatus is thickened but not calcified. The Wilkins score of this valve was calculated to be about 8 , indicating suitabi lity for PBMV. ${ }^{5}$

\section{Commissure fusion}

Commissural fusion can be assessed from the PSAX display used for planimetry. However, the anatomy of the commissures may be difficult to assess, particularly in patients with severe valvular abnormalities. Commissures are better visualized using real-time 3D echocardiography. Commissural fusion in patients with rheumatic MS can be seen in Figure 16.6,15

Commissural fusion is an important feature for differentiating rheumatic MS from degenerative MS and for checking the consistency of severity measures. Complete fusion of the two commissures generally indicates severe MS. 6.16

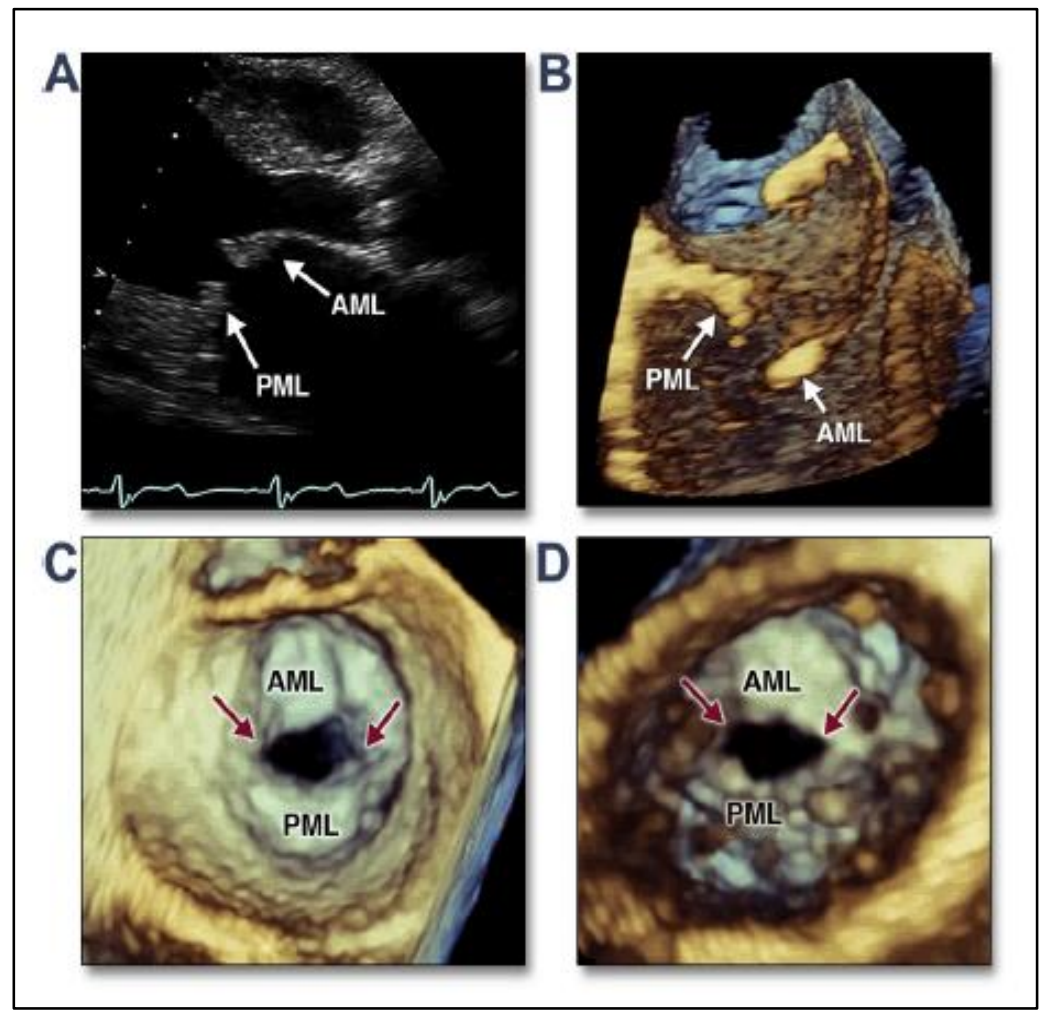


Figure 5. A typical example of rheumatic MS. (A) Leaflet thickening at the edges is shown in the PLAX display. (B) Posterior leaflet immobility and anterior leaflet doming as typical morphological characteristics of rheumatic mitral valve disease are shown in a 3-dimensional transoesophageal image. 3-dimensional transesophageal images of the left atrial aspect (C) and the left ventricular aspect (D) showing the fusion of the two commissures (red arrow). AML = anterior mitral leaflet; $\mathrm{PML}=$ posterior mitral leaflet. 15

\section{Calcification}

Calcifications are identified by bright echogenic dots above the leaflet. $5,11,16$ How to calculate the commissural calcification score by looking at the dots that show high intensity echo brightness can be seen in Figure 6.15

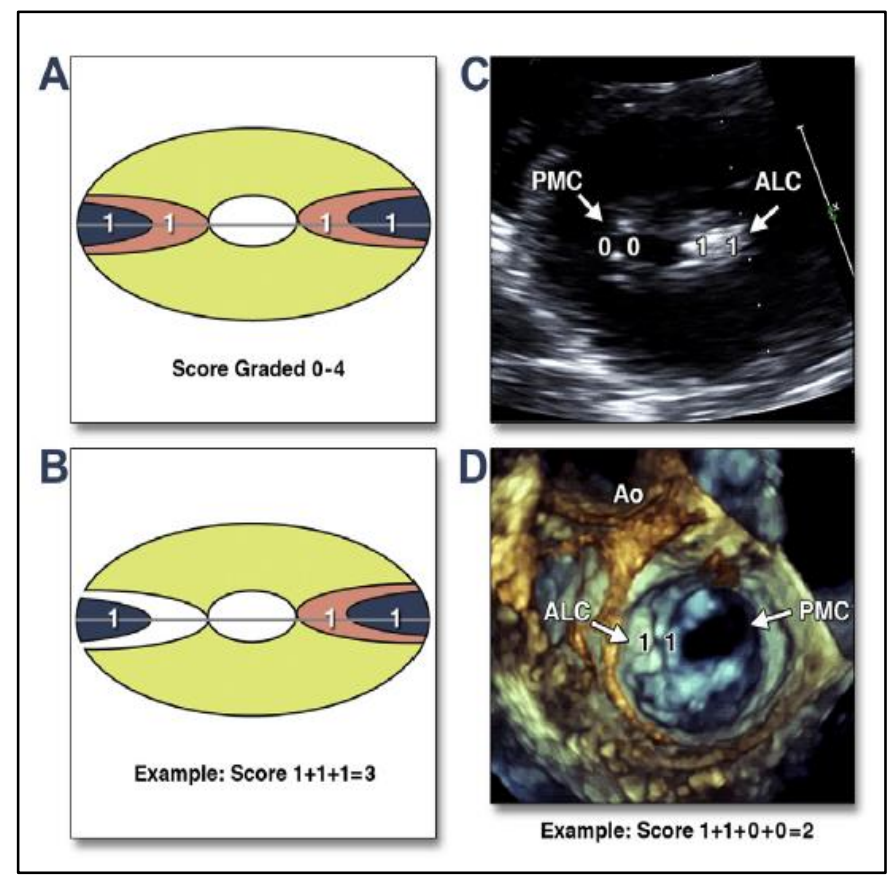

Figure 6. Evaluation of the Komisura Calcification Score. Commissural calcifications were calculated by assigning each half of the commissures (anterolateral and posteromedial) with detectable high intensity echo brightness with a score of 1 . Commissural calcifications ranged from grade 0 (no calcification) to grade 4. (A) Both commissures were completely calcified. (B) An example where half the commissure is calcified on the left side and the entire commissure is calcified on the right side, then the value is 3. (C) 2D PSAX display at the level of the mitral leaflet shows that only 1 commissure is completely calcified, whereas the other commissures do not show calcification. (D) Left atrial aspect 3D TEE view. The score calculated in this example is 2 . ALC = anterolateral commissure; Ao = aorta; $\mathrm{PMC}=$ posteromedial commissure. 15

\section{Stenosis Severity Assessment}

The assessment of mild, moderate and severe MS depends on the valve area, mean transmitral gradient and peak tricuspid regurgitation gradient (TR) according to the guidelines established by the ESE and
ASE (table 7). There are several other parameters to assess the severity of MS such as separation of the two mitral leaflets and estimation of valve area by Doppler, half-life pressure and continuity equations. ${ }^{11}$

Table 7. Classification of severity of mitral stenosis based on ESE/ASE*.6,11 


$\begin{array}{lll}\text { Light } & \text { Medium } & \text { Weight }\end{array}$

Specific findings $\left(\mathrm{cm}^{2}\right)$

- Valve area

$>1.5$

$1.0-1.5$

$<1.0$

Supportive findings (mmHg)

- Mean gradient

$<5$

$5-10$

$>10$

- Pulmonary artery pressure

$<30$

$30-50$

$>50$

* Heart rate between 60-80 in sinus rhythm

\section{Mitral valve area planimetry (level 1 recommendation)}

Theoretically, planimetry using 2D echocardiography of the mitral orifice has the advantage of obtaining a direct measurement of the mitral valve area (MVA) independent of flow conditions, cardiac chamber compliance, or associated valve lesions. In practice, planimetry has been shown to have the best correlation with the anatomic area of the valve, for this reason planimetry is considered as a reference for measuring MVA. 6

Planimetric measurements were obtained by direct tracing of the mitral orifice, including the commissure opening, as seen on the PSAX view. Careful scanning from the apex to the base of the LV is required to ensure that the cross sectional area (CSA) is measured at the tip of the leaflet. The measuring plane should be perpendicular to the mitral orifice, which has an elliptical shape (Figure. 7). $6,15,16$

The gain setting should be good enough to visualize the entire contour of the mitral orifice. The optimal time of the cardiac cycle for measuring planimetry is middiastole. This is best done using cineloop mode on a frozen image. 6

Planimetric measurements require technical expertise. The measuring plane should be optimally positioned in the mitral orifice. Recent reports suggest that real-time 3D echo (figure 7) ${ }^{15}$ and 3D-guided biplane imaging are useful in optimizing the position of the measuring plane. 6

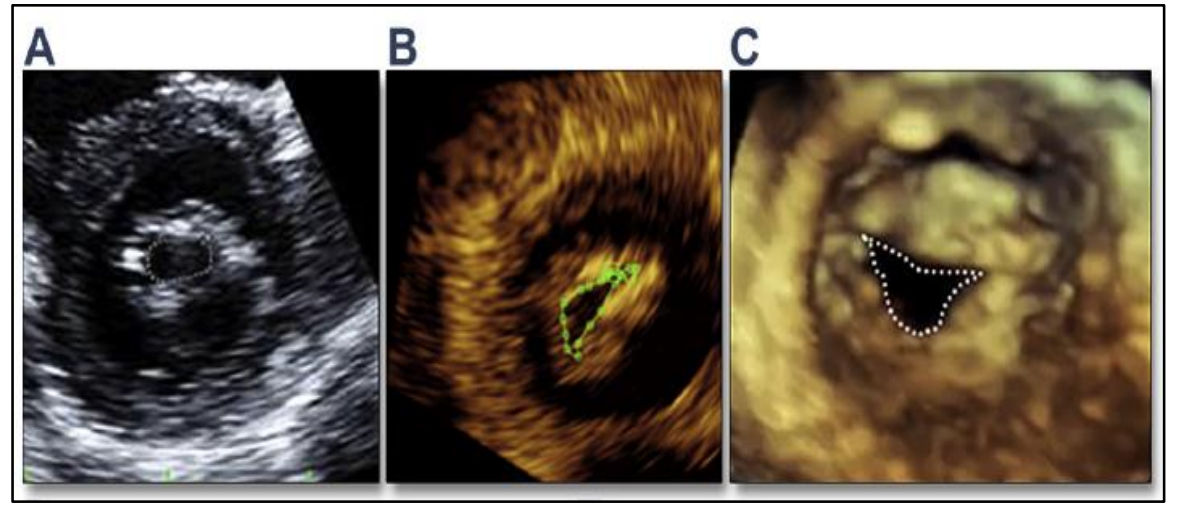

Figure 7. Planimetric method for evaluating MVA with 2D and 3D echoes. (A) Planimetric measurements of the 2D 
PSAX view. (B) Using 3D TEE. (C) Direct depiction of MVA in 3D TEE images (left ventricular aspect). 15

Planimetry is a routine examination that must be carried out in clinical practice. However, routine evaluation of MS severity should incorporate measurements of the mean gradient and IPM methods.
Some recommendations for routine measurement methods that can be carried out in clinical practice are listed in table 8.6

Table 8. Recommendations for recording and measuring data in routine use for quantitation of mitral stenosis. 6

\begin{tabular}{|c|c|c|}
\hline Data Element & Recording & Measurement \\
\hline \multirow[t]{4}{*}{ Planimetry } & - PSAX 2D view & - Contour in the mitral orifice \\
\hline & $\begin{array}{l}\text { - Determine the smallest hole by scanning } \\
\text { from apex to basal }\end{array}$ & - Includes commissure when opened \\
\hline & $\begin{array}{l}\text { - 3D echo-oriented measurement plan } \\
\text { placement }\end{array}$ & - In mid-diastole (use cine-loop) \\
\hline & $\begin{array}{l}\text { - Lowest gain setting to visualize the } \\
\text { entire mitral space }\end{array}$ & - Average measurement if atrial fibrillation \\
\hline \multirow[t]{3}{*}{ Mitral flow } & - Continuous wave Doppler (CWD) & $\begin{array}{l}\text { - Mean gradient of the traced contour of } \\
\text { the diastolic mitral flow }\end{array}$ \\
\hline & $\begin{array}{l}\text { - Apical window is often appropriate } \\
\text { (optimize intercept angle) }\end{array}$ & $\begin{array}{l}\text { - Pressure half-life of the descending slope of } \\
\text { the E wave (mid-diastolic slope if not linear) }\end{array}$ \\
\hline & $\begin{array}{l}\text { - Adjust gain settings to get well-defined } \\
\text { flow contours }\end{array}$ & - Average measurement if atrial fibrillation \\
\hline \multirow[t]{2}{*}{$\begin{array}{l}\text { Systolic } \\
\text { pulmonary artery } \\
\text { pressure Tekanan }\end{array}$} & - Continuous wave Doppler & $\begin{array}{l}\text { - Maximum velocity of tricuspid regurgitation } \\
\text { flow }\end{array}$ \\
\hline & $\begin{array}{l}\text { - Multiple acoustic windows to } \\
\text { optimize intercept angle }\end{array}$ & $\begin{array}{l}\text { - Estimate right atrial pressure according to } \\
\text { the diameter of the inferior vena cava }\end{array}$ \\
\hline \multirow[t]{7}{*}{ Valve anatomy } & - PSAX display & $\begin{array}{l}\text { - Valve thickness (maximum and } \\
\text { heterogeneity) } \\
\text { - Commissure fusion } \\
\text { - Expansion and location of localized bright } \\
\text { zones (fibrous or calcified nodules) }\end{array}$ \\
\hline & - PLAX display & - Valve thickness \\
\hline & & - Calcification expansion \\
\hline & & - Valve flex \\
\hline & & $\begin{array}{l}\text { - Subvalvular apparatus (cord thickening, } \\
\text { fusion, or shortening) }\end{array}$ \\
\hline & - A2C display & $\begin{array}{l}\text { - Subvalvular apparatus (cord thickening, } \\
\text { fusion, or shortening) }\end{array}$ \\
\hline & & $\begin{array}{l}\text { Detail each component and summarize it in a } \\
\text { score }\end{array}$ \\
\hline
\end{tabular}




\section{Mitral leaflet separation index}

This mitral leaflet separation index is measured in the PLAX display and the A4C display. The distance between the ends of the leaflets when the wide separation at the time of diastolic is measured for at least three cardiac cycles and then the average is taken. Index $\leq 0.8 \mathrm{~cm}$ predicts severe MS, index $1.1-1.2$ or more indicates mild MS. 11

\section{Pressure gradient (recommended level 1)}

The diastolic estimated pressure gradient is obtained from the velocity of the transmitral flow using the Bernouli equation, $\mathrm{P}=4 \mathrm{v}^{2}$. The use of continous wave doppler (CWD) is preferred to ensure maximum velosity. When pulsed wave Doppler (PWD) is used, the sample volume should be placed at the level or after the leaflet tips (valve leaf tip). 6,11

Gradient Doppler is assessed using the apical view in most cases because it allows for parallel alignment of the ultrasound beam and the incoming mitral stream, this minimizes the angle of intercept with the

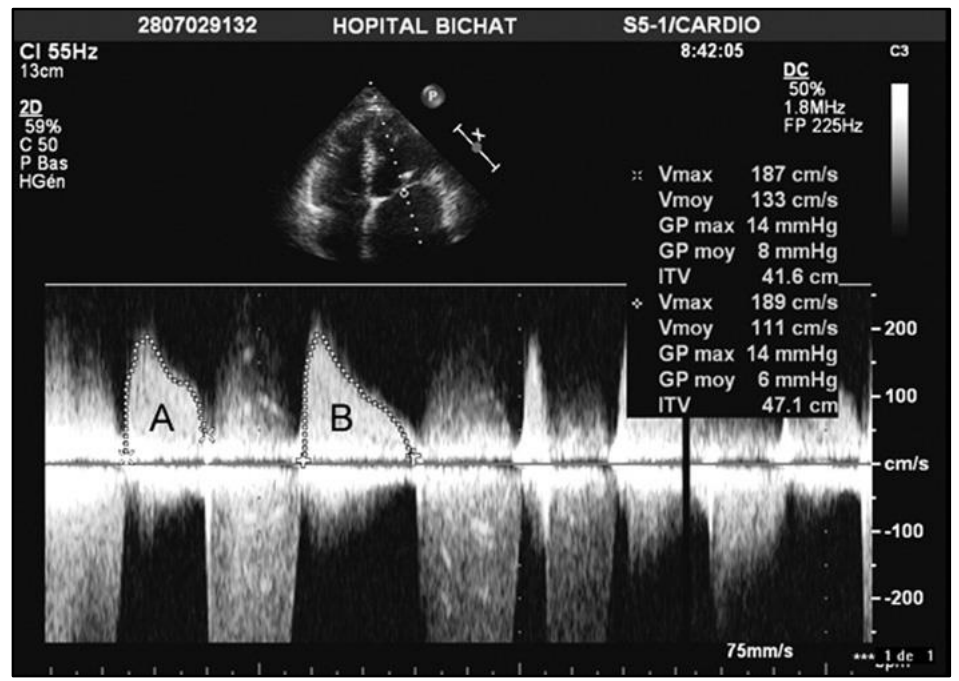

Figure 8. Determination of the mean mitral gradient in a severe MS patient with atrial fibrillation. The mean gradient varies according to diastolic length: $8 \mathrm{mmHg}$ during short diastolic (A) and $6 \mathrm{mmHg}$ during longer diastolic (B). 6

\section{Part-time pressure (IPM) (level 1 recommendation)}

Pressure half-time (IPM) is defined as the time interval in milliseconds between the maximum mitral gradient at the beginning of diastolic and the time point at which the gradient is half the maximum initial value. Valve area $\left(\mathrm{cm}^{2}\right)$ is inversely proportional to the decrease in velocity (velocity) of transmitral flow during mitral stream in order to avoid unreliable velosity results. Color Doppler in the apical view is useful for identifying the mitral eccentric jet during diastole which may be encountered in cases of severe deformity of the valvular and subvalvular apparatus. In this case, the Doppler beam is guided by the zone of highest flow velocity identified by the Doppler heat. 6

Optimization of gain settings, beam orientation and good acoustics is required to obtain a clear contour of the Doppler flow. The maximum and mean mitral gradient are calculated by the integrated software using a trace of the transmitral Doppler spectral waveform during diastolic on the monitor screen. The gradient mean is a relevant hemodynamic feature (Fig. 8). While the maximum gradient is less attractive because it comes from the peak mitral velocity (peak mitral velocity), which is influenced by left atrial compliance and left ventricular diastolic function. 6

(1)




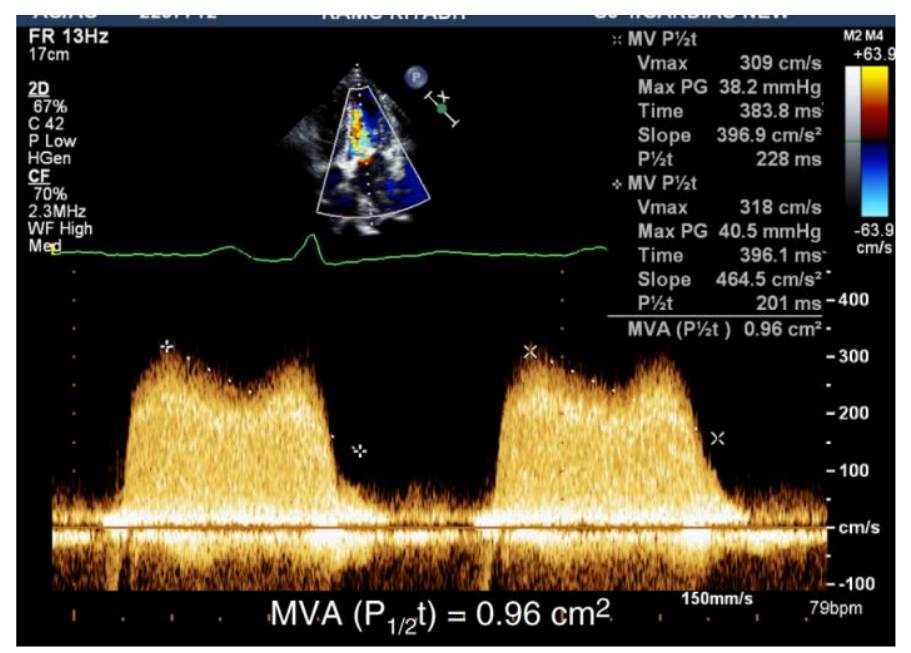

Figure 9. Calculation of the mitral valve area (MVA) using the half-life pressure method $(\mathrm{PTH}=\mathrm{P} 1 / 2 \mathrm{t}) .5$

Occasionally, mid-diastolic flow is higher than early diastolic, so the IPM method cannot be used to assess MS (figure 10). When the transmitral flow does not have homogeneous decelerations, the initial part of the slope can be neglected (first $300 \mathrm{~ms}$ ) and IPM can be obtained from the mid-diastolic slope. ${ }^{11}$

The half-life pressure is highly dependent on the

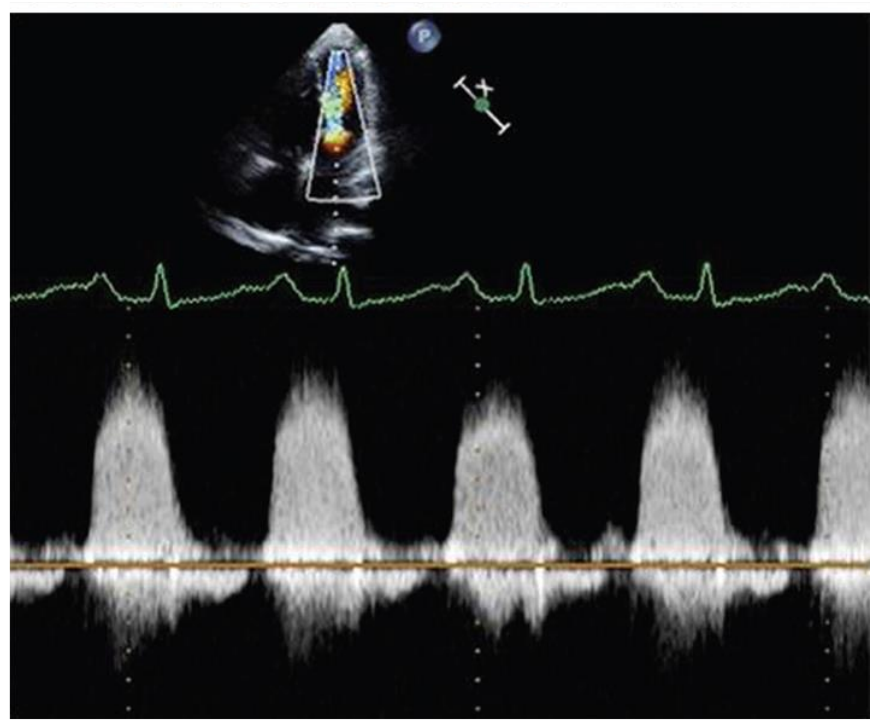

Figure 10. This spectral Doppler waveform, only the gradient can be measured, while the IPM cannot be measured. ${ }^{11}$

The weaknesses of IPM are as follows: 11

1. If concurrent aortic regurgitation (AR) is significant, it increases LV end-diastolic pressure, lowers the late diastolic gradient between LA and LV, causing a decrease in PHT orifice of the mitral valve. However, IPM is also affected by LA and LV diastolic compliance, initial transmitral gradient and LA contractile strength. The half-life pressure is less dependent on heart rate and transmitral flow so it can be used in various $R$ intervals such as atrial fibrillation. ${ }^{11}$ 
overestimation of the MVA.

3. If LV relaxation is abnormal, for example: LV hypertrophy, then the deceleration time and IPM are prolonged, causing an underestimated MVA.

Patients with atrial fibrillation, at the time of tracing should avoid short diastolic slopes and take long diastolic slopes with 5 different cardiac cycles, then take the average value of the 5 cycles. 6,11 The IPM method is widely used because it is easy to do, will but has some limitations that affect the relationship between IPM and MVA. 6

\section{Continuity equation (Level 2 recommendation)}

The continuity equation, as in the estimation of the aortic valve area (AVA), is based on the law of conservation of mass and assumes that the volume of blood flowing through the mitral annulus during diastole must equal that flowing across the mitral orifice (equal to the sample volume of the aorta). The mitral annulus can be replaced with a left ventricular outflow tract (LVOT). This substitution only applies if there is no significant AR. So that MVA can be assessed using the formula below. $6,11,18$

$$
\begin{aligned}
& \boldsymbol{M V} \boldsymbol{A}=\boldsymbol{\pi}\left(\frac{\boldsymbol{D}^{\mathbf{2}}}{\mathbf{4}}\right)\left(\frac{\boldsymbol{V T I}_{\text {aortic }}}{\boldsymbol{V T} \boldsymbol{I}_{\text {mitral }}}\right) \\
& \Pi \quad: 3,14 \\
& \mathrm{D} \quad: \text { diameter LVOT }(\mathrm{cm}) \\
& \text { VTI : Velocity time integral }(\mathrm{cm})
\end{aligned}
$$

An example of measuring MVA using the continuity equation method can be seen in Figure 11.6,11

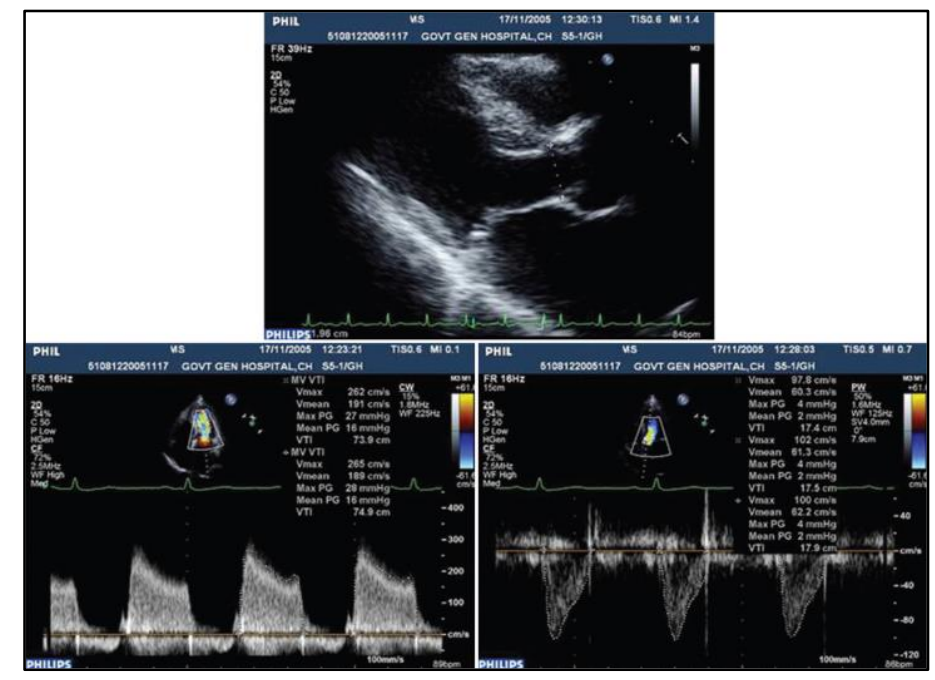

Figure 11. MVA with continuity equation (a) PLAX display for measuring left ventricular outflow tract (LVOT) diameter (b) A4C display for measuring velocity time integral (VTI) of mitral stenosis (c) A5C display for measuring VTI LVOT. In the picture the diameter of LVOT $=1.96 \mathrm{~cm}$, VTI LVOT $=17.4 \mathrm{~cm}$, VTI mitral $=74.9 \mathrm{~cm}$, then $\mathrm{MVA}=1.96 \times 1.96$ $\times 0.785 \times 17.4 / 74.9=0.7 \mathrm{~cm}^{2} .11$

\section{Proximal isovelocity surface area (PISA) method (Level 2 recommendation)}

The basic principles of the PISA method are 1) Flow dynamic properties; 2) The principle of continuity. The PISA method or proximal surface area isovelocity is based on the hemispherical shape of the convergence of diastolic mitral flow on the atrial side of the mitral valve, as demonstrated by calor Doppler. This allows the volume of mitral flow to be assessed. Thus, to determine MVA by dividing the volume of mitral flow by the maximum velocity of diastolic mitral flow assessed by CWD. The formula used to measure MVA using the PISA method can be seen below. 4,17,18

$$
\begin{array}{ll}
\boldsymbol{M V A}= & \mathbf{2 \pi} \boldsymbol{r}^{\mathbf{2}} \times\left(\frac{\boldsymbol{V}_{\boldsymbol{a l}}}{\boldsymbol{V}_{\text {max }}}\right) \times\left(\frac{\boldsymbol{\alpha}}{\mathbf{1 8 0}^{\circ}}\right) \\
\mathrm{r} & : \text { radius of convergent hemisphere }(\mathrm{cm}), \\
\mathrm{V}_{\mathrm{al}} & : \text { aliasing speed }(\mathrm{cm} / \mathrm{s}),
\end{array}
$$


$\mathrm{V}_{\max } \quad$ : peak velocity of mitral flow by $\mathrm{CWD}(\mathrm{cm} / \mathrm{s})$,

$\alpha$

: mitral leaflet opening angle relative to the direction of flow

This method can be used in patients with significant MR. However, it is technically demanding and requires a lot of measurement. Its accuracy is affected by the uncertainty in the measurement of the radii of the convergent hemisphere and the opening angle. How to take the size of the radius of convergence and opening angle can be seen in Figure 12A. 6,19

In some $\mathrm{V}_{\text {aliasing }}$ studies it is used as a constant value and the central valve angle can be fixed by $100^{\circ}$ in the PISA equation based on previous study reports, then the MVA calculated by PISA can be simulated by leaving only two variables, namely PISA radius and
Vmax which is known as the simple PISA method. (PISAsimple). The equation calculation between ordinary PISA (conventional PISA) and simple PISA (PISA simple) can be seen below. 18,20

$$
\begin{aligned}
\text { PISA }_{\text {simple }} & =2 \pi r^{2} \times\left(V_{\text {al }} / V_{\text {max }}\right) \times(\alpha / 180) \\
& =2 \times 3,14 \times r^{2} \times\left(33 / V_{\text {max }}\right) \times(100 / 180) \\
& =(2 \times 3,14 \times 33 \times 100 / 180) \times\left(r^{2} / V_{\max }\right) \\
& =115 \times r^{2} / V_{\max }
\end{aligned}
$$

So the calculation using the simple PISA method only requires the measurement of two variables, namely the PISA radius ( $r$ ) and the peak velocity of the mitral flow (Vmax) as assessed by CWD. An example of measurement with PISAsimple can be seen in Figure 12.20

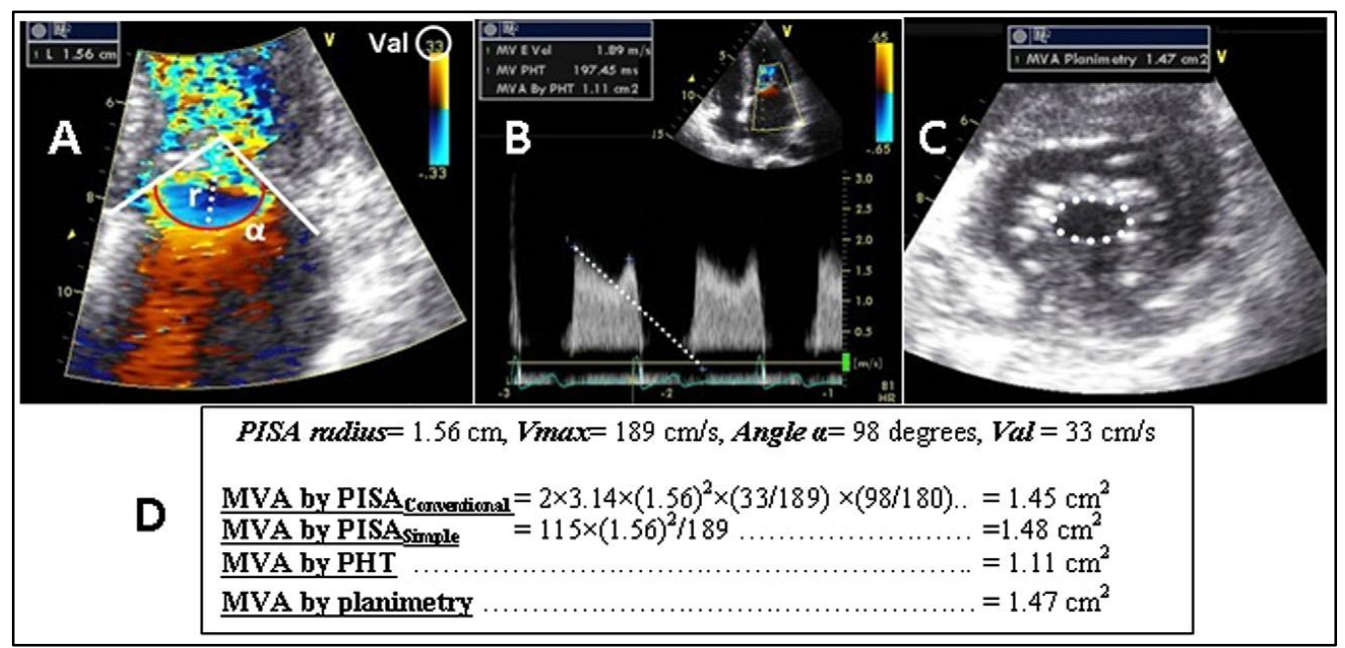

Figure 12. Calculation of MVA with different methods; A, PISA method. B, IPM method. C, planimetric method. and D, examples of MVA calculations using various methods show a good match between planimetry, conventional PISA and simple PISA, but do not apply to IPM

\author{
Mitral valve resistance (MVR) (Level 3 \\ recommendation) \\ Mitral valve resistance is defined as the ratio of the \\ mean mitral gradient (MPG) to the transmitral diastolic \\ flow rate, which is calculated by dividing the sample \\ volume by the diastolic filling period. Mitral valve \\ resistance is an alternative measure of MS severity, \\ which is less dependent on flow conditions. Mitral valve \\ resistance correlates well with pulmonary artery \\ pressure, but has not been shown to have added value \\ for assessing the severity of MS compared to valve
}

area. ${ }^{6}$

Pulmonary artery pressure estimates, using Doppler estimation of the systolic gradient between the right ventricle (RV) and right atrium (RA), reflect the consequences of MS more than the severity itself. Pulmonary artery pressure is important for clinical decision making.4 Mitral valve resistance is calculated from the equation which is represented as the metric unit adynes.sec/ $\mathrm{cm}^{5} .21,22$ 


$$
\begin{array}{cl}
\boldsymbol{M V R}=\frac{\boldsymbol{M P G}}{\frac{\boldsymbol{L V O T}_{\boldsymbol{d}} \times \boldsymbol{L V O T}}{\boldsymbol{D F T I}}} \\
\text { MVR } & : \text { mitral valve resistance } \\
\text { MPG } & : \text { mean transmitral pressure gradient } \\
\text { LVOTd } & : \text { LV outlet diameter } \\
\text { LVOTVTI } & : \text { channel time integral speed exit LV } \\
\text { DFT } & : \text { diastolic filling time (diastolic filling } \\
& \text { time) }
\end{array}
$$

The LVOT diameter is rated in the PLAX display and the LVOTVTI is rated in the A5C display with PWD. Display A4C for assessing DFT, starting from the beginning of wave $\mathrm{E}$ to the end of wave A. Display A4C is also used to assess transmitral MPG using CWD.19,20 Here we can also calculate cardiac output $(C O)=($ LVOTVTI $) \times 0.785 \times($ LVOTd $) 2 \times($ HR $) .22$

In another study, MVR was calculated using a simpler variable by including the conversion factor

\section{Another role of echocardigraphy in the evaluation of mitral stenosis}

Another valve disease frequently associated with rheumatic MS is aortic stenosis (AS). The severity of AS

Tricuspid valve analysis should look for signs of involvement of the arthritic process. More often, associated with tricuspid disease is functional TR.6 Calculation of the estimated right ventricular systolic pressure $($ RVSP $)=$ systolic pulmonary artery pressure (sPAP), can then be calculated from the modified Bernoulli equation: $\mathbf{R V S P}=\mathbf{~} \mathbf{P A P}=\mathbf{4 V 2}+$ right atrial pressure, where ' $\mathrm{V}$ ' is the maximum speed of the
(1333) in the formula with metric units (dynes.sec/cm5) with the equation:23

$$
M V R=\frac{1333 \times T M P G_{\text {mean }}}{Q}
$$

Conversion factor $\quad: 1333$

$\mathrm{Q}$ : transmitral diastolic flow velocity $(\mathrm{mL} / \mathrm{s})$

TMPGmean : mean of transmitral pressure gradient $(\mathrm{mmHg})$

Where $\mathrm{Q}$ is calculated as the stroke volume divided by the diastolic filling period. Stroke volume is measured as LVOT diameter, LVOT time integral velocity (VTI), and continuity equation.

can be underestimated because decreasing sample volume to MS reduces the aortic gradient, so it is necessary to estimate the aortic valve area (AVA). In cases of severe aortic regurgitation (AR), the IPM method for MS assessment is invalid. 6

tricuspid valve regurgitation jet. 5,21

All approaches to measuring the severity of mitral stenosis have their advantages and disadvantages. In terms of discrepancy, planimetric results are reference measurements, except with poor acoustic performance. The advantages and disadvantages of each method for evaluating mitral stenosis can be seen in table $9 .{ }^{6}$ 
Table 9. Approach to evaluation of mitral stenosis.10

\begin{tabular}{|c|c|c|c|c|c|}
\hline Measurement & Unit & Formula/Method & Concept & $\begin{array}{c}\text { Advantage } \\
\mathbf{s}\end{array}$ & Deficiency \\
\hline $\begin{array}{l}\text { Valve area } \\
\text { - Planimetry with } \\
\text { 2D echo }\end{array}$ & $\mathrm{cm}^{2}$ & $\begin{array}{l}\text { Tracing the mitral orifice } \\
\text { using } 2 \mathrm{D} \text {. echo }\end{array}$ & $\begin{array}{l}\text { Direct } \\
\text { measureme } \\
\text { nt of the } \\
\text { anatomy of } \\
\text { the MVA } \\
\text { anatomy }\end{array}$ & $\begin{array}{l}\text { - Accurate } \\
\text { - Free from } \\
\text { other } \\
\text { factors }\end{array}$ & $\begin{array}{l}\text { - Experience required } \\
\text { - Not always suitable } \\
\text { (bad acoustic window, } \\
\text { heavy valve } \\
\text { calcification }\end{array}$ \\
\hline $\begin{array}{l}\text { - Part time } \\
\text { pressure (IPM) }\end{array}$ & $\mathrm{cm}^{2}$ & 220/PHT & $\begin{array}{l}\text { The rate of } \\
\text { drop in } \\
\text { transmissio } \\
\mathrm{n} \text { flow is } \\
\text { inversely } \\
\text { proportional } \\
\text { to MVA }\end{array}$ & $\begin{array}{l}\text { Easily } \\
\text { obtained }\end{array}$ & $\begin{array}{l}\text { Dependence on other } \\
\text { factors(AR, RA complian } \\
\text { ce, LV diastolic } \\
\text { function, ...) }\end{array}$ \\
\hline $\begin{array}{l}\text { - Continuity } \\
\text { equation }\end{array}$ & $\mathrm{cm}^{2}$ & $\begin{array}{l}\text { MVA=(CSA LVOT })(V T I \text { Aortic } \\
\text { )/ VTI Mitral }\end{array}$ & $\begin{array}{l}\text { Volume } \\
\text { flows throu } \\
\text { gh the } \\
\text { mitral and } \\
\text { orifice are } \\
\text { the same }\end{array}$ & $\begin{array}{l}\text { Free from } \\
\text { flow } \\
\text { conditions }\end{array}$ & $\begin{array}{l}\text { - Multiple } \\
\text { measurements } \\
\text { (source of error) } \\
\text { - Invalid if AR or MR is } \\
\text { significant }\end{array}$ \\
\hline - PISA & $\mathrm{cm}^{2}$ & $\begin{array}{l}2 \pi r^{2} \text { (Valiasing) / Peak } \\
\text { VMitral x a / } 180 \text { o }\end{array}$ & $\begin{array}{l}\text { MVA is } \\
\text { assessed by } \\
\text { dividing the } \\
\text { mitral } \\
\text { volume flow } \\
\text { by the } \\
\text { maximum } \\
\text { diastolic } \\
\text { mitral flow } \\
\text { rate }\end{array}$ & $\begin{array}{l}\text { Free from } \\
\text { flow } \\
\text { conditions }\end{array}$ & Technically difficult \\
\hline Mean gradient & $\mathrm{mmHg}$ & $\Delta \mathrm{P}=\Sigma 4 \mathrm{v} 2 / \mathrm{N}$ & $\begin{array}{l}\text { The } \\
\text { pressure } \\
\text { gradient is } \\
\text { calculated } \\
\text { from the } \\
\text { velocity } \\
\text { using the } \\
\text { Bernoulli } \\
\text { persamaan } \\
\text { equation }\end{array}$ & Easy to get & $\begin{array}{l}\text { Depends on heart rate } \\
\text { and flow conditions }\end{array}$ \\
\hline $\begin{array}{l}\text { Systolic } \\
\text { pulmonary artery } \\
\text { pressure (sPAP) }\end{array}$ & $\mathrm{mmHg}$ & $\begin{aligned} \mathrm{sPAP}= & 4 \mathrm{v} 2 \text { Tricuspid } \\
& +\mathrm{RA} \text { pressure }\end{aligned}$ & $\begin{array}{l}\text { Addition of } \\
\text { RA pressure } \\
\text { and RA } \\
\text { gradient } \\
\text { between RV } \\
\text { and RA. }\end{array}$ & $\begin{array}{l}\text { Obtained } \\
\text { in the } \\
\text { majority of } \\
\text { patients } \\
\text { with MS }\end{array}$ & $\begin{array}{l}\text { - Variable estimates of } \\
\text { RA . pressure } \\
\text { - No estimate of } \\
\text { pulmonary vascular } \\
\text { resistance }\end{array}$ \\
\hline $\begin{array}{l}\text { Mean } \\
\text { gradient and systo } \\
\text { lic pulmonary } \\
\text { artery pressure } \\
\text { during exercise }\end{array}$ & $\mathrm{mmHg}$ & $\begin{aligned} & \Delta \mathrm{P}=\Sigma 4 \mathrm{v} 2 / \mathrm{N} \\
& \mathrm{sPAP}= 4 \mathrm{v} 2 \text { Tricuspid } \\
&+\mathrm{RA} \text { pressure }\end{aligned}$ & $\begin{array}{l}\text { Gradient } \\
\text { assessment } \\
\text { and sPAP to } \\
\text { increase } \\
\text { workload - }\end{array}$ & $\begin{array}{l}\text { Additional } \\
\text { value in } \\
\text { tolerance } \\
\text { assessmen } \\
\mathrm{t}\end{array}$ & $\begin{array}{l}\text { - Experience required } \\
\text { - Lack of validation for } \\
\text { decision making }\end{array}$ \\
\hline Valve Resistance & $\begin{array}{l}\text { dyne s } \\
\text { s ec / cm }\end{array}$ & $\begin{array}{l}\mathrm{MVR}=\mathrm{P}_{\text {Max }} / \\
{\left[(\mathrm{CSALVOT})\left(\mathrm{VTI}_{\text {Aortic }}\right) / \mathrm{D}\right.} \\
\text { FT }]\end{array}$ & $\begin{array}{l}\text { Resistance } \\
\text { to flow } \\
\text { caused by } \\
\text { MS. }\end{array}$ & $\begin{array}{l}\text { Initially } \\
\text { suggested } \\
\text { to be } \\
\text { less flow- } \\
\text { dependent } \\
\text {, but no } \\
\text { confirmati } \\
\text { on }\end{array}$ & $\begin{array}{l}\text { No prognostic value. } \\
\text { There is no clear } \\
\text { threshold for severity } \\
\text { No added value vs valve } \\
\text { area }\end{array}$ \\
\hline
\end{tabular}

Recommendation level: in all patients (yellow); selective patients with rationality (green); not recommended (blue). 
AR, Aortic regurgitation ; CSA, cross-sectional area ; DFT, diastolic filling time ; LA, left atrium ; LV, left ventricle ; LVOT, left ventricular outflow tract; MR, mitral regurgitation; MS, mitral stenosis; MVA, mitral valve area; MV R, mitral valve resistance $; \Delta \mathrm{P}$, gradient; $\mathrm{PPAP}$, systolic pulmonary artery pressure $; \mathrm{r}$, the radius of the convergence hemisphere; RA, right atrium ; RV, right ventricle ; IPM , pressure half-time ; v, velocity ; VTI, integral velocity time ; N, number of instantaneous measurements .

\section{Conclusion}

Echocardiography is the most important diagnostic tool in the evaluation of MS aiming to confirm the etiology, assess the severity of the stenosis, recommend the type and timing of intervention, to assess other valvular lesions, presence of thrombus, and vegetations. The European Society of Echocardiography/American Society of Echocardiography has developed several guidelines on measurement methods for clinical practice which are categorized into three levels of recommendation. The routine methods recommended by EAE/ASE to be performed in clinical practice are as follows: planimetric method, IPM, mean gradient and pulmonary artery systolic pressure. In case of discrepancy, planimetric results are reference measurements, except with poor acoustic performance.

The results of this echocardiography examination can be a basis for consideration for patient management of the selected therapeutic procedure while still considering indications, contraindications and prognostic aspects.

\section{References}

1. Dal-Bianco JPand LevineRA. Anatomy of the mitral valve apparatus - role of $2 \mathrm{D}$ and $3 \mathrm{D}$ echocardiography. Cardiol Clin. 2013; 31(2): 1-23.

2. McCarthy KP, Ring L, and Rana BS. Anatomy of the mitral valve: understanding the mitral valve complex in mitral regurgitation. European Journal of Echocardiography. 2010; 11: i3-i9.

3. Ranjan R and Pressman GS. Aetiology and epidemiology of mitral stenosis. E-Journal of Cardiology Practice, Vol. 16 Vol. Jun 2018. Available at $:$ https://www.escardio.org/Journals/E-
Journal-of-Cardiology-Practice/Volume-

16/Aetiology-and-epidemiology-of-mitral-stenosis

4. Indrajaya T, Ghanie A. Stenosis mitral. Dalam: Sudoyo AW, Setiyohadi B, editor. Buku ajar ilmu penyakit dalam jilid I. Jakarta: Pusat Penerbitan Departemen Ilmu Penyakit Dalam FKUI; 2014. hal.1171-79.

5. Omran AS, Arifi AA and Mohamed AA. Echocardiography in mitral stenosis. Journal of the Saudi Heart Association 2011; 23: 51-8.

6. Baumgartner H, Hung J, Bermejo J, Chambers JB, Evangelista A, et al. Guidelines and Standards Echocardiographic Assessment of Valve Stenosis: EAE/ASE Recommendations for Clinical Practice European Society of Cardiology 2008: 1-23.

7. Permataranny MB, Yanni M dan Permana H. Profil penderita stenosis mitral reumatik di RSUP Dr. M. Djamil Padang tahun 2012-2016. Jurnal Kesehatan Andalas. 2019; 8(1):28-36.

8. Neema PK. Pathophysiology of Mitral Valve Stenosis. MAMC J Med Sci 2015;1:25-7.

9. Faletra FF, Nucifora $G$ and Ho SY. Echocardiography anatomy of the mitral valve. In: Faletra FF, editor. Echocardiography in Mitral Valve Disease. (C) Spinger-Verlag Italia 2013. P. 1-22.

10. Prokšelj k. Echocardiography of mitral valve. University Medical Centre Ljubljana. Slovenia 2017. P: 26-41. Doi: 10.5644/PI2017.168.03.

11. Ganesan G. How to assess mitral stenosis by echo A step by step approach. J Indian Acad Echocardiogr Cardiovasc Imaging 2017:1-9.

12. Mughal S, Hanif MI, Riaz A and Hanif A. Wilkin's Score; Prediktive value of Wilkin's score in 
determining the prosedural success of percutaneuos transvenous mitral commissurotomy. Professional Med J 2018; 25(9): 1432-7.

13. Soliman OI, Anwar AM, Metawei AK, McGhie JS, GeleijnseML, et al. New scores for the assessment of mitral stenosis using real-time three-dimensional echocardiography. Curr Cardiovasc Imaging Rep 2011; 4:370-7.

14. Shiota T, Oemar H. Bising dan Penyakit Katup Jantung. Dalam: Oemar H, editor. Textbook of echocardiography, interpretasi dan diagnosis klinik. Jakarta: Yayasan Mencerdaskan Bangsa (YMB). 2005. hal.117-35.

15. Wunderlich NC, Beigel $\mathrm{R}$ and Siegel RJ. Management of mitral stenosis using 2D and 3D echo-Doppler imaging. JACC : Cardiovascular Imaging 2013; 6 (11): 1-15.

16. Ghanie A. Pengantar diagnosis Ekokardiografi. Dalam: Sudoyo AW, Setiyohadi B, editor. Buku ajar ilmu penyakit dalam jilid I. Jakarta: Pusat Penerbitan Departemen Ilmu Penyakit Dalam FKUI; 2014. hal.1107-17.

17. Lindman BR and Arnold SV. Mitral valve disease. In: Rasalingam R, Makan M, Perez JE, editor. The Washington Manual of Echocardiography.Wolters Kluwer Health. Lippincott Williams \& Wilkins. P. 128-48.

18. Haji GF, AlRaghi MJ and Mualla NK. Assessment of mitral valve stenosis by simplifying proximal isovelocity surface area in Iraqi patients by transthoracicechocardiography. Int J Med Res Health Sci 2018; 7(2): 84-91.

19. Messika-Zeitoun D, Cachier A, Brochet E, Cormier B, Lung B and Vahanian A. Evaluation of mitral valve area by the proximal isovelocity surface area method in mitralstenosis: Could it be simplified? Eur J Echocardiography 2007; 8: 116-21.

20. Omar AMS, Abdel-Rahman MA, Tanaka $\mathrm{H}$ and Rifaie O. Simplifying proximal isovelocity surface area as an assessment method of mitral valve area in patients with rheumatic mitral stenosis by fixing aliasing velocity and mitral valve angle. J Saudi Heart Assoc 2013; 25: 9-17.

21. El-Dosouky II and Meshrif AM. Role of the mitral valve resistance in evaluation of mitral stenosis severity. J Med Diagn Meth 2016; 5:1

22. Roshdy HS, Amir M. Meshrif AM, El-Dosouky II. Value of the mitral valve resistance in evaluation of symptomatic patients with mild and moderate mitral stenosis - A dobutamine stress echocardiographic study. Wiley Periodicals, Inc. Echocardiography 2013; 347-52.

23. Sanati H, Zolfaghari R, Samiei N, Rezaei Y, Chitsazan M et al. Mitral valve resistance determines hemodynamic consequences of severe rheumatic mitral stenosis and immediate outcomes of percutaneous valvuloplasty. Wiley Periodicals, Inc. Echocardiography 2017;1-7. 